\title{
Spin-Off and Commercialization of University Researches
}

\author{
Nguyen Duc Minh'1, Tran Thi Hai Van² \\ ${ }^{1}$ Ho Chi Minh City University of Technology, Ho Chi Minh City, Vietnam \\ ${ }^{2}$ Hanoi University of Mining and Geology, Hanoi, Vietnam \\ Email: nd.minh@hutech.edu.vn, tranthihaivan@humg.edu.vn
}

How to cite this paper: Minh, N. D., \& Van, T. T. H. (2022). Spin-Off and Commercialization of University Researches. Open Journal of Social Sciences, 10, 256-266. https://doi.org/10.4236/jss.2022.101021

Received: December 18, 2021

Accepted: January 21, 2022

Published: January 24, 2022

Copyright (c) 2022 by author(s) and Scientific Research Publishing Inc. This work is licensed under the Creative Commons Attribution International License (CC BY 4.0).

http://creativecommons.org/licenses/by/4.0/

\begin{abstract}
This paper analyzes the university spin-off which is considered as a new solution to exploit and commercialize current university research. Since the function of universities is research and training, not production, their researches or inventions are often academic and fundamental in nature. The need to convert research results into machines or equipment that can be used in industrial production has created a spin-off enterprise in the university. A spin-off is one of the bases for commercializing research results of universities. With the method of analyzing and synthesizing results from related studies, the study provides recommendations for effective spin of development as a useful solution for improving the commercialization of research results in universities.
\end{abstract}

\section{Keywords}

University Researches, Commercialization, Industrial Production, Spin-Off

\section{Introduction}

Currently, the efficiency of commercializing research results in universities is not high. The reason is that universities almost exclusively focus on training and scientific research tasks. In addition to the active communication system, modern universities in the world also focus on other jobs such as linking with the business sector and gradually play an important role in the economic development of the country ethnic. Accordingly, many universities have focused on the commercial exploitation of modern companies through scientific research activities, which not only greatly contributes to economic growth and development but also a source of economic growth economic growth provides cutting-edge technology upgrades to industry players. Among the models of commercializa- 
tion of scientific research, the establishment of subsidiary enterprises by universities is considered an important mechanism to improve this efficiency. This business industry first appeared in England at the end of the nineteenth century and quickly gained attention and application in developed countries around the world.

\section{Literature Review}

\subsection{Definition of Spin-Off (or Spin-Off Enterprise)}

According to Oxford Dictionary (online) a spin-off is "A subsidiary of a parent company that has been sold off, creating a new company." Similarly, the Cambridge Advanced learner's dictionary \& thesarus (online) also defines a spin-off is "A new business created by separating part of company, or the act of creating such a business."

In this study, spin-off is a new company formed by selling or distributing shares of an existing business or division of the parent company. Furthermore, spin-offs are expected to be more valuable as independent entities rather than parts of a larger business. Spin-off is a type of divestiture and is also known as spin out. The university is not a manufacturing enterprise, so it has to form spin-off businesses to deploy ideas, models, and results of scientific research into machinery and equipment or to cooperate with external units in the production and technology transfer. There are three different types of spin-offs with associated characteristics: equity carveouts, split-offs, and split-ups.

- Under equity carve-outs, a portion of the subsidiary's shares is offered for sale to the public. This has the effect of injecting money into the parent company without loss of control.

- A split-offs occurs when shareholders exchange their parent stock for the shares of the subsidiary. These transactions give the company the opportunity to dispose of a subsidiary in a tax-free manner, and even to remove an unwanted shareholder.

- Under a split-ups, the parent company distributes shares of each subsidiary, and the parent company liquidates and ceases to exist.

Thus, spin-off operations are likely to yield some new results such as:

- The generation of new revenue from scientific research at universities in addition to tuition fees.

- The transformation of a passive perspective into an active one concerning the productive activities of society.

- The formation of a leadership class of the university with a flexible economic management mindset.

- The creation of a link in the value chain to meet market requirements.

- Ensuring a sustainable triple helix model including state enterprise-university.

- The enhancement of the university's performance and position in the national innovation system and international relations.

- The encouragement of lecturers to participate in scientific research activities.

- The addition of experience from practical activities and relevant lecture up- 
dates.

- The implementation of real market orientation in the university's activities.

- The addition of experience from practical activities and relevant lecture updates.

- The implementation of real market orientation in the university's activities. Some of the top spin-offs in the world are shown in Table 1

\subsection{Commercialization of University Researches}

According to modern economic theories, national development is associated with scientific and technological capacity. National competitiveness is expressed by the preeminent characteristics of products in the market and all products are the result of scientific research and technological innovation.

Therefore, economic development must be closely linked to national technological research and innovation, and at the national level, research of universities and academies plays a decisive role in research and innovation. However, research results of universities are often solutions and applications, while industry wants new machinery and equipment, technological lines that can be evaluated for features and effectiveness of research results. To meet these industry requirements, the university must either cooperate with investors or on its own set up a new business-spin-off enterprise-to convert or transfer the results of academic research (Iacobucci \& Micozzi, 2015).

This is a relatively new research problem for Vietnamese universities, and lecturers and managers in Vietnamese universities have little experience in production and business activities, so the quantitative research through questionnaire survey may not be satisfactory. Therefore, the study uses the method of analysis and synthesis of results from related studies at home and abroad. On the basis of previous research results and the current situation of our country, we will propose solutions to develop spin-off in order to commercialize scientific research results of universities to meet the requirements of the industry.

\subsection{Review of Relevant Conditions for Spin-Off Operation}

\subsubsection{Macro Environment}

Each country defines its own development strategy in accordance with its own characteristics, which always includes the development strategy of Science, Technology and Innovation (STI) because STI determines competitiveness of countries in the world (Broughel \& Thierer, 2019). The adoption of new technologies can improve productivity and innovation makes processes more efficient and companies can provide higher quality goods and services. Investments in research and development $(\mathrm{R} \& \mathrm{D})$, and innovation boosts production capacity and support overall growth. Much empirical and theoretical work focuses on research and development as an important factor for economic growth. R\&D spending leads to growth through its positive effects on innovation and total factor productivity (TFP).

Due to the outstanding features of science and technology, which is to compete 
Table 1. Top spin-offs.

\begin{tabular}{|c|c|c|c|c|}
\hline \multicolumn{2}{|c|}{ No.Spin-off } & \multirow{2}{*}{$\begin{array}{l}\text { University } \\
\text { Harvard University, } \\
\text { USA }\end{array}$} & \multirow{2}{*}{$\begin{array}{l}\text { Activities or products } \\
\text { A highly sensitive, nucleic acid-based diagnostic platform to rapidly } \\
\text { deliver accurate and inexpensive results, transforming diagnostic testing } \\
\text { and global public health, be it in hospitals, industrial settings, or at home. }\end{array}$} & \multirow{2}{*}{$\begin{array}{l}\text { Founded } \\
\text { year } \\
2019\end{array}$} \\
\hline 1 & $\begin{array}{l}\text { Sherlock } \\
\text { Biosciences }\end{array}$ & & & \\
\hline 2 & FenX & $\begin{array}{l}\text { ETH Zurich, } \\
\text { Switzerland }\end{array}$ & $\begin{array}{l}\text { High-performance insulation foams made from abandoned waste } \\
\text { materials and it is also fully recyclable, emits low } \mathrm{CO}_{2} \text { emissions, and is } \\
\text { economically competitive. }\end{array}$ & 2019 \\
\hline 3 & $\begin{array}{l}\text { PolyProx } \\
\text { Therapeutics }\end{array}$ & $\begin{array}{l}\text { Cambridge University, } \\
\text { UK }\end{array}$ & $\begin{array}{l}\text { A new class of drugs. Polyproxin }{ }^{\mathrm{TM}} \text {, has great potential to treat cancer and } \\
\text { neurodegenerative diseases. }\end{array}$ & 2019 \\
\hline 4 & SpeQtral & $\begin{array}{l}\text { National University of } \\
\text { Singapore }\end{array}$ & $\begin{array}{l}\text { Space-based quantum communication systems rooted in advanced } \\
\text { technologies and unprecedented security from eavesdropping and enable } \\
\text { the next generation of secure communication networks. }\end{array}$ & 2019 \\
\hline 5 & DeepCure & MIT Media Lab, USA & $\begin{array}{l}\text { Artificial intelligence with deep learning, cloud computing, and a } \\
\text { proprietary database of one trillion chemistries is to enable the discovery } \\
\text { of highly effective drugs and to revolutionize pharmaceutical development. }\end{array}$ & 2018 \\
\hline 6 & $\begin{array}{l}\text { Echopoint } \\
\text { Medical }\end{array}$ & $\begin{array}{l}\text { University College } \\
\text { London, UK }\end{array}$ & $\begin{array}{l}\text { Fiber optic sensor technology to develop cutting-edge cardiovascular } \\
\text { devices that provide sensing and imaging capabilities in minimally } \\
\text { invasive procedures. }\end{array}$ & 2018 \\
\hline 7 & HIT Nano & $\begin{array}{l}\text { Princeton University } \\
\text { scientists \& Silicon } \\
\text { Valley entrepreneurs, } \\
\text { USA }\end{array}$ & $\begin{array}{l}\text { Materials for thermal chemical energy storage, optical imaging, chemical } \\
\text { synthesis and next-generation, low cost and highperformance Li-Ion } \\
\text { batteries and energy storage systems by using novel high-temperature } \\
\text { nanotechnologies. }\end{array}$ & 2018 \\
\hline 8 & $\begin{array}{l}\text { Canopus } \\
\text { Networks }\end{array}$ & $\begin{array}{l}\text { University of New South } \\
\text { Wales, Australia }\end{array}$ & Artificial intelligence to optimize the use of bandwidth in data networks. & 2018 \\
\hline 9 & TWAICE & $\begin{array}{l}\text { Technical University of } \\
\text { Munich, Germany }\end{array}$ & $\begin{array}{l}\text { Develop and use battery systems more efficiently and sustainably while } \\
\text { making them more reliable and durable. }\end{array}$ & 2018 \\
\hline 10 & AgroSustain & $\begin{array}{l}\text { University of Lausanne, } \\
\text { Switzerland }\end{array}$ & $\begin{array}{l}\text { Natural solutions to stop and prevent the development of molds on } \\
\text { agronomically important crops pre- and post-harvest. }\end{array}$ & 2018 \\
\hline 11 & $\begin{array}{l}\text { Versatope } \\
\text { Therapeutics }\end{array}$ & Cornell University, USA & $\begin{array}{l}\text { A technology platform that uses exosomes derived from genetically } \\
\text { engineered probiotics used in vaccines, therapeutics and diagnostics. }\end{array}$ & 2017 \\
\hline 12 & Fifth Eye & $\begin{array}{l}\text { University of Michigan, } \\
\text { USA }\end{array}$ & $\begin{array}{l}\text { A medical device software building clinical early warning systems for } \\
\text { hospitals to improve the quality and cost of care. }\end{array}$ & 2017 \\
\hline 13 & $\begin{array}{l}\text { Cybrexa } \\
\text { Therapeutics }\end{array}$ & Yale University, USA & $\begin{array}{l}\text { AlphalexTM technology that allows small molecule anti-cancer agents to } \\
\text { penetrate cell membranes only at low } \mathrm{pH} \text {, can selectively release drug } \\
\text { molecules directly within tumor cells while limiting toxicity to healthy } \\
\text { tissue. }\end{array}$ & 2017 \\
\hline 14 & $\begin{array}{l}\text { Avisi } \\
\text { Technologies }\end{array}$ & $\begin{array}{l}\text { University of } \\
\text { Pennsylvania, USA }\end{array}$ & $\begin{array}{l}\text { A nanoscale ocular implant to stop blindness in Open Angle Glaucoma } \\
\text { patients, the second leading cause of blindness in the world that has no } \\
\text { available cure currently. }\end{array}$ & 2017 \\
\hline
\end{tabular}

Source: Thomson, A. (2019). The top new university spin-offs you should know. Available at

https://blog.ventureradar.com/2019/11/18/the-top-new-university-spin-offs-you-should-know/\#: :text=AgroSustain $\% 20 \% 28$ Switzerl and $\% 2$ C $\% .202018 \% 29 \% 20$ is $\% 20$ a $\% 20$ spin-ff $\% 20$ from $\% 20$ the,of $\% 20$ vegetables $\% 20$ and $\% 20$ fruits $\% 20$ infected $\% 20$ with $\% 20$ common $\% 2$ 0molds. 
in the market and in order to create a leading position, many countries and territories around the world have focused on policies to develop spearhead science and technology industries. The UNCTAD Technology and Innovation Report 2021 addresses that the national and international policies, instruments and institutional reforms with the result of frontier technologies already represent a $\$ 350$ billion market and is likely to increase to $\$ 3.2$ trillion by 2025 .

To achieve the Sustainable Development Goals all countries need to pursue science, technology and innovation policies appropriate to their development stage and economic, social and environmental conditions. Countries worldwide have to compete to win the global innovation race, so they face different challenges. In fact, the nation that can effectively manage three sides of the innovation success triangle is like to be a nation that wins the race and reap the rewards of greater economic growth and prosperity (Atkinson, 2020).

In recent years, international trade has expanded rapidly due to the rise of global value chains (GVCs). As a result, it has helped developing countries grow faster, spurring economic growth and reducing poverty. On the contrary, new challenges from the emergence of technologies like AI, automation, etc. make the labor-intensive model no longer acceptable. Thus, innovative policies can drive growth, create jobs and reduce poverty (IBRD, 2019). The world is moving through a new production phase with better environmental requirements. Policymakers must orient national innovation policies towards green, sustainable and inclusive development in accordance with the climate and development goals. Innovation activity in any country is embedded in the national innovation system (NIS) and innovation is not only science and technology but also includes many other factors including economic institutions, other political and social influences that influence innovation (e.g., policies and regulations, financial systems; business organizations; labor markets; higher education systems; culture and tax incentives).

More than ever, economic stability, good governance, sound regulations and the provision of basic infrastructure remain essential to attracting the investments needed to increase regional production and support economic integration. In particular, strategic business clusters and the establishment of special economic zones, in which governments provide access to quality infrastructure and reliable regulation, can further support industrialization and regional specialization.

\subsubsection{University}

The higher education community can contribute solutions to strengthen leadership, technological innovation and development orientation, strategic vision to implement a multi-faceted, sustainable campaign to maintain, enhance prosperity and long-term prospects without the need for massive new capital. Institutional research plays a vital role in national innovation. This study focuses on the activities of universities on technological capacity development in countries and economic regions. Scientific research activities of universities have long played a 
very important role in the national innovative new development system and promote national economic growth.

Many scientific research results have made great contributions to solving urgent national problems. For the leading countries in the world such as the United States, Japan, the European Union, etc., scientific research in universities is an extremely important part of the national development strategy (Ivano, 2018). Universities play an essential role in the growth of the nation. The university's research and innovation solves technology gaps, encourages investment, promotes exports, and creates a thriving economy. University research activities train a highly skilled and innovative workforce that underpins the success of the knowledge-based economy. The UK's fastest growth stems from boosting productivity, increasing socioeconomic efficiency. This result is rooted in world-leading research and innovation by universities and policies that support the most effective collaboration between universities and industry.

The UK creates an amazing and diverse research and innovation ecosystem that is a key driver of growth and productivity: IP revenue alone generated $£ 86,6$ million in 2012-2013, $£ 376$ million from graduate start ups and another $£ 2,7$ billion from partnerships with businesses.

\subsubsection{Cooperation Model}

National innovation programs to create competitive advantage across the country require daily changes in factors affecting value-added chains such as polities and regulations, institutional actors, interactions and relationships. Practice cutting-edge research capabilities, external partnerships, quantification of scientific knowledge and output, and collective entrepreneurship that facilitate growth. To improve the quality and efficiency of their production, businesses need to partner with academic institutions to tackle technological challenges and share industry knowledge. The government acts as an assistant organization with the right policy, and the venture capitalists act as evaluators and investors to fund operations. In that context, technology innovation cooperation becomes an activity linking universities-industry-government under the model of "Triple Helix" in order to maintain the sustainable development of a country (Etzkowitz, 2021). Because the university (parent organization) does not have a production function, it is necessary to set up a business-called a spin-off enterprise-to develop ideas, solutions, and inventions into specific machines and equipment to put into production (Benassi et al., 2017).

The establishment of a spin-off is a very important activity that transforms the university mindset into an enterprise mindset in meeting industry requirements by transferring technology from the university to the industry. Spin-off may include not only members of the school but also outside members such as investors or venture capital funds. Although there are many types of spinoffs, the importance of spin-off universities as a technology transfer mechanism for creating and sustaining regional economic growth is widely recognized. Universities have established organizational mechanisms and procedures to encourage 
spin-off activities: provision of laboratory facilities, access to research equipment, skilled labor, specialized facilities and expertise. For example, Stanford University in Silicon Valley, MIT on 128th Street, and the University of Texas at Austin have a good relationship with their spin-offs. Products of spin-offs such as mass-market fingerprint recognition device, severe storm forecasting via short-range X-band radar arrays, minimally invasive surgery (da Vinci robot), artificial retina, increased fuel economy through hybrid hydraulic systems (tested in prototype and near-market vehicles). Electrical vehicles, mobile payments and Artificial Intelligence, smart cities initiatives and smart technologies have catalysed private investment in recent years, particularly by technology firms, telecommunications, utilities and transport companies, and real estate developers. More than ever, economic stability, good governance, sound regulation and the provision of basic infrastructure remain essential to attracting the investments needed to increase regional production and support economic integration.

In particular, strategic business clusters and the establishment of special economic zones, in which governments provide access to quality infrastructure and reliable regulation, can further support regional industrialization and specialization. Both the spin-off business and the parent institution (university) perceive spin-off formation as a win-win situation. Spin-off sometimes have some conflicts with the university (their parent institution) and need to negotiate on the sharing of income from the exploitation of the intellectual property rights of the transferred technology. In order to develop sustainable relation between the university and spin-offs, in the United States, the Bayh-Dole Act was enacted to protect the faculty's right in the distribution of financial income from results of university researches that is funded by the budget. "The U.S. Bayh-Dole Act (P.L. 96-517, 94 Stat. 3015, codified at 35 U.S.C. $\$ \$ 200-211$ ) allows universities, not-for-profit organizations, and small businesses to retain certain IP rights related to inventions made via federally supported R\&D. Serving as the statutory foundation facilitating federally supported R\&D technology transfer, the Act was designed to promote commercialization of innovations arising from such $R \& D$ through cooperation between the research community, industry, and state and local governments."

\subsubsection{Investors}

In the beginning, although there is a lot of growth potential from the exploitation of inventions and technology transfer that generates high profits, spin-off may face difficulties in business capital. Moreover, it is difficult for them to get loans from banks and credit institutions due to limited collateral and business documents. Meanwhile, venture capital has been investing in small and medium-sized enterprises _SMEs operating in the high-margin innovation sector. With the business philosophy of "high risk and big return", the venture capital fund has invested in many manufacturing industries and achieved outstanding business results in developed countries. Venture capital has created a business 
partnership model with SMEs. In addition to capital investment, the venture capital fund also provides mentoring, industry networking and support to grow the business.

This model has played an active role in providing capital to develop super-profitable technology businesses in the United States such as Apple, Amazon, Alphabet (Google), Microsoft, Facebook, etc. On the basis of the model's achievements in the United States, venture capital funds develop very quickly in capitalist countries around the world.

\subsubsection{Status of Innovation Activities in Vietnam}

In recent years, Vietnam's innovation activity has grown and in 2019 Vietnam became the first among the group of 29 lower-middle-income economies. Results are shown in Table 2.

The results of scientific research have contributed to good solutions such as Ton That Tung's liver surgery, frozen semen method in In Vitro Fertilisation (IVF), organ transplantation from donated tissues, stem cells from umbilical cord membranes, hematopoietic stem cell transplantation to treat blood diseases, fetal intervention techniques, wheelchairs controlled through human thought, fire suppression by sound waves, water measurement methods in agriculture, etc.

However, scientific research of universities is not regular and has not met the requirements of society and national development, the added value and contribution to GDP is still very small. School officials are not familiar with the flexible operating mechanism of enterprises. The number of scientific and technological (S\&T) research groups and the investment in equipment are lacking and inconsistent. The necessary policies and legal regulations to develop S\&T activities are lacking and inconsistent. The results of S\&T researches have not been proven through production practices, so businesses have not been persuaded to use them.

Table 2. Lower-middle-income economies (29 in total).

\begin{tabular}{ccc}
\hline No. & Countries & World ranking \\
\hline 1 & Viet Nam & 42 \\
2 & Ukraine & 45 \\
3 & India & 48 \\
4 & Philippines & 50 \\
5 & Mongolia & 58 \\
6 & Republic of Moldova & 59 \\
7 & Tunisia & 65 \\
8 & Morocco & 75 \\
9 & Indonesia & 85 \\
10 & Kenya & 86 \\
\hline
\end{tabular}

Source: Cornell, INSEAD, and WIPO, 2020. pp. G. 
Although market demand for advanced technology is high, universities do not have favorable environment to commercialize research products and the spin-off model has not yet developed. Science and technology research activities in most universities are not only academic in nature (including the number of published articles and the number of scientific research topics) but also not associated with the need for technological innovation of the industry. Funding for S\&T activities can only be used from the university's budget or from provinces and ministries, but not from enterprise.

Thus, in the most general understanding, the spin-off model is an enterprise operating in the field of science and technology, originating mainly from universities, research institutes or by individuals or collectives, researchers wishing to break away from the parent organization to develop research and business on their own. The main goal of the spin-off business is to become a place where scientific and technological researches of universities, research institutes and scientists are applied, developed and maximized commercial exploitation.

\section{Recommendations}

\subsection{Government}

First of all, the Government should incorporate the national innovation system development strategy into the national development strategy and promulgate a policy on developing the national innovation system, as well as pay attention to the development of the triple helix model and the spin-off model in scientific research units. Next, it is important to increase the share of budgets for scientific research in universities and to identify the key technologies to be achieved in the direction of national competition and to order units with strong scientific research capacity. Additionally, it is necessary to invest in national laboratories of international stature for scientific research, and to cooperate with other countries to learn and share experiences. Moreover, it is not only necessary to amend the intellectual property law in accordance with the requirements of integration, but also to ensure the harmonization of interests among stakeholders in exploiting research results from the budget, as well as identifying tax incentives in scientific research, new products and issuing policies to attract venture capital. Finally, it is vital to expand cooperation with developed countries in scientific research and engage leading researchers in key government projects.

\subsection{Enterprises}

Enterprises should formulate a development strategy in accordance with the new requirements of the world and the national strategy, including orientations for sustainable development and green production.

In addition, it is necessary for enterprises to actively participate in the development programs of the national innovation system including the triple helix model and spin-off model, and to strengthen cooperation with the university's scientific research as well. Besides, enterprises should dynamically take part in 
national programs on key technologies and cooperate with industry associations in developed countries to gain experience in scientific research. Moreover, it is important for enterprises to ensure the harmonization of interests among stakeholders in technology transfer cooperation and advocacy for tax incentives for science and technology enterprises and new products. Finally, enterprises should innovate comprehensive management of all activities in the business, relations with state management agencies and customers as well.

\subsection{Universities}

Firstly, universities leaders should develop a growth strategy of university in line with the national innovation system development strategy and actively participate in the development of the triple helix model, as well as the establishment of spin-offs and technology transfer office (TTO). In addition, it is important for universities to consider scientific research not only as a brand-building activity, but also as a second income-generating activity. Furthermore, universities should provide material and legal support for spin-off activities and determine appropriate income among stakeholders in exploiting research results and technology transfer according to provisions of law.

Besides, it is necessary for university to expand the spin-off operation with the guarantee, relationships and reputation of the university and resolve conflicts arising with the spin-off by negotiation on the basis of long-term benefits as well. At the same time, universities should strengthen connection with industry associations to promptly grasp innovation requirements and periodically organize thematic activities with industries to jointly solve problems arising from enterprises.

Next, it is critical for university to engage with national laboratories in scientific research, to expand cooperation with developed countries across multiple channels of relations to share scientific research experiences as well as to promulgate regulations on attracting venture capital investment in exploiting research results and technology transfer. Moreover, universities should rationally allocate faculty activities between teaching and scientific research responsibilities and apply a special regime with top talents in science and technology in the formation and operation of strong research groups.

Finally, it is urgent for university to train legacy human resources in science and technology through practical researches, expand relationship with businesses, industry associations, provinces, cities, ministries, national programs and projects, etc. to meet the development requirements of the society.

\section{Conclusion}

COVID-19 pandemic has disrupted supply chains in the world, formed new international trade relations and sustainable development trends that require improved production conditions, technological innovation, investing in environmentally friendly production, reduction of $\mathrm{CO}_{2}$ emissions according to the 2030 
objectives of the United Nations. Green economy development requires control of pollution in industry, efficient use of natural resources, no harm to the environment and nature. Vietnam promotes exports through trade agreements and Vietnamese enterprises must innovate technology to survive in the international market. In addition, technological innovation improves productivity to avoid the middle-income trap, export barriers in the world and limits future dependence on foreign technology.

In the coming time, research to develop and innovate technology in industries is an urgent requirement of research institutions and enterprises. In order to quickly put research results into production, it is necessary to form many spinoffs with strong technology transfer capacity, effective operation to increase connectivity, and quickly respond to market requirements. In fact, in the chain of value-creating activities to implement Vietnam's STI strategy, spin-off activities play a very important role. As a result, it is a bottleneck in the formation of a technology innovation ecosystem and effectively solving this bottleneck will promote the coordination between universities and industries, and develop the country's economy in the integration period. Finally, in order to achieve these issues, it is imperative to improve and synchronous coordinate between the three parties: government, business and research institutions including universities

\section{Conflicts of Interest}

The authors declare no conflicts of interest regarding the publication of this paper.

\section{References}

Atkinson, R. (2020). Understanding the U.S. National Innovation System, 2020. The Information Technology \& Innovation Foundation (ITIF).

Benassi, M., Landoni, M., \& Rentocchini, F. (2017). University Management Practices and Academic Spin-Offs. Working Paper 11/2017, Università degli studi di Milano, Dipartimento di Economia, Management e Metodi Quantitativi.

Broughel, J., \& Thierer, A. (2019). Technological Innovation and Economic Growth: A Brief Report on the Evidence. Mercatus Center at George Mason University. https://doi.org/10.2139/ssrn.3346495

Etzkowitz, H. (2021). Innovation in Innovation: The Triple Helix of University-IndustryGovernment Relations. Social Science Information, 42, 293-337. https://doi.org/10.1177/05390184030423002

Iacobucci, D., \& Micozzi, A. (2015). How to Evaluate the Impact of Academic Spin-Offs on Local Development: An Empirical Analysis of the Italian Case. The Journal of Technology Transfer, 40, 434-452. https://doi.org/10.1007/s10961-014-9357-8

IBRD (2019). World Development Report 2020. Trading for Development in the Age of Global Value Chains. International Bank for Reconstruction and Development/The World Bank.

Ivano, D. (2018). Universities Third Mission as a Drive for Academic Spin-Offs Creation and Regional Development. ASO Performance Indicators and External Influencing Factors: A Literature Review. International Journal of Business and Social Science, 9, 48-53. https://doi.org/10.30845/ijbss.v9n5a6 